\title{
CYTOTOXIC EFFECTS OF TITANIUM ALLOY ORTHODONTIC MINI-SCREW IMPLANTS: CLINICAL PROSPECTIVE STUDY
}

\author{
Ahmed S.M. Ammar ${ }^{*}$, Hussein N. Al-Khalefa ${ }^{* *}$, Ashraf A.A. El-Bedwehi ${ }^{* * *}$ and Mohamed I. Aref ${ }^{* * * *}$
}

\begin{abstract}
Objectives: to evaluate possible cytotoxic effects of titanium alloy (Ti alloy) orthodontic miniscrew implants on the surrounding oral mucosal cells.

Materials and Methods: Thirty orthodontic mini-screw implants (MSIs) installed to serve as anchorage for maxillary canine retraction after maxillary first premolar extraction. Fifteen female orthodontic patients with mean age of $16.11 \pm 1.68$ years were consented to participate in the study, which ran for four months. The orthodontic appliance consisted of direct-bonded Roth monocrystalline ceramic brackets, and teflon-coated preformed archwires. Clinical evaluation of MSIs and oral hygiene condition were evaluated throughout the study period. Percentage of oral mucosa cells' DNA fragmentation were analyzed before insertion of MSIs, after one week, one month, three months and four months of MSIs insertion with the Comet assay analysis.
\end{abstract}

Results: ANOVA test showed statistically significant decrease in oral hygiene condition during the study period. Statistically insignificant difference was evident in DNA fragmentation index of the collected oral mucosal cell in different time intervals.

Conclusions: Orthodontic titanium alloy MSIs were biocompatible and demonstrated no cytotoxic effects on oral mucosal cells.

KEYWORDS: Canine retraction, Mini-screw implants, DNA Fragmentation, Comet assay.

\section{INTRODUCTION}

Orthodontic treatment incorporating MSIs as an anchorage was introduced at the end of the last century. Then MSIs became widely used to sustain orthodontic and orthopedic forces, turning into effective orthodontic anchorage devices. ${ }^{1,2}$
Firstly, commercially pure titanium (CP-Ti) was the material of choice to produce mini-implants owing to its; high bio-compatibility, high corrosion resistance in body fluids, not allergic, and acceptable strength if used in a large diameter. Actually, orthodontic MSIs have a small diameter and should

\footnotetext{
* Assistant Lecturer of Orthodontics, Faculty of Dental Medicine (Boys), Al-Azhar University, Cairo, Egypt. ** Assistant Professor of Orthodontics, Faculty of Dental Medicine (Boys), Al-Azhar University, Cairo, Egypt. *** Professor of Orthodontics, Faculty of Dental Medicine (Boys), Al-Azhar University, Cairo, Egypt. **** Professor of Clinical Pathology, Faculty of Medicine (Boys), Al-Azhar University, Cairo, Egypt.
} 
resist high orthodontic loads. To avoid fracture of MSIs and improve its mechanical properties, Ti alloy implants, composed of titanium, aluminum $(6 \mathrm{Al})$ and vanadium $(4 \mathrm{~V})$, have been introduced. ${ }^{2-4}$

Into the oral envelope, various factors as saliva, oral fluids, the enzymatic behavior, microbial activity, $\mathrm{pH}$ fluctuation, and temperature fluctuation interact together, creating an ideal condition for aqueous corrosion of implanted metals and alloys giving rise to potential metal ion release..$^{5-7}$

The released metal ions (titanium, aluminum, and vanadium) could induce localized inflammation, clinical failure of the MSIs, cutaneous allergic reactions, hypersensitivity, cytotoxicity, carcinogenesis, and possible genotoxicity. ${ }^{8-11}$

The clinical studies ${ }^{7,12}$ evaluating the cytotoxic effects of metal ions released from orthodontic miniscrew implants in body fluids were limited. Various in vitro studies was conducted to evaluate metal ions released from MSIs and its cytotoxic effects on cell culture..$^{5,6,8-11}$ However, material biocompatibility tested by in vitro methods were lacking the simulation of the oral cavity with its multifactorial environment. So, the current study was conducted to investigate clinically the biological effects of commercial orthodontic mini-screw implants on the oral investing tissue.

\section{SUBJECTS AND METHODS}

Subjects: The current study was conducted on thirty Ti alloy orthodontic MSIs placed in fifteen female orthodontic patients (mean age of $16.11 \pm$ 1.68 years) to serve as an absolute anchorage for maxillary canine retraction. Patients were recruited from Orthodontic Clinic, Faculty of Dental Medicine (Boys), Al-Azhar University, Cairo. All miniscrew implants were removed after four months of insertion, once maxillary canine retraction was completed in one patient. Ethical approval was obtained from the regional committee for medical and health research ethics, faculty of Medicine (boys), Al-Azhar University, Cairo, Egypt.
Sample size calculation was based on power of statistics analysis, using the standard deviation of cell viability in a previous study results. ${ }^{11}$ For an alpha 0.05 , delta $=-0.3500, \mathrm{p} 0=0.3600$, $\mathrm{pa}=$ 0.01 , and power of 0.80 ; the estimated sample size for a one-sample proportion test(score $\mathrm{z}$ test) was calculated to be 7 orthodontic MSIs.

The inclusion criteria: 1) patients indicated for bilateral extraction of maxillary first premolar,2) Good oral and general health (Free of any disease that could affect the oral mucosa),3) All teeth should be free from caries or any metallic restorations.

The exclusion criteria: 1)history of occupational exposure to metals, 2) seriously fractured appliance, 3 ) deteriorated oral hygiene condition, and/or 4) broken appointment.

\section{Orthodontic intervention:}

For each patient, fixed orthodontic appliance (figure 1) consisted of: 1) direct bond, pre-adjusted Roth ceramic brackets (0.022" X 0.028")(Perfect clear, HUBIT Crystal Sapphire Brackets, South Korea), 2) teflon-coated nickel titanium round arch wires (Aethetic archwires, Ortho-Organizer, USA) (0.012", 0.014", 0.016", 0.018") for the leveling and alignment stage, if needed, and teflon-coated stainless steel arch wires $(0.018$ ") for the canine retraction, 3) the arch wires were ligated by clear latex-free elastic O-ties, 4) Self-drilling (SD) orthodontic MSI (Tomas-Pin SD, Dentaurum, Germany) $(1.6 \mathrm{~mm}$ in diameter, $8 \mathrm{~mm}$ in thread length, gingival collar $(2.8 \mathrm{~mm}$ maximum diameter, $2 \mathrm{~mm}$ in height), and a head with cross slot $2.25 \mathrm{~mm}$ in height) was used as an anchorage for maxillary canine retraction. ${ }^{2}$

An insertion guide was used to standardize the receptor site between maxillary first molar and second premolar. The wire was inserted into the first molar bracket slot with a coil at the other end of the wire to locate accurately the vertical $(6-8 \mathrm{~mm}$ from the bracket slot apically) and anterioposterior (center of inter-dental bone) position of the MSI. The MSI was directed perpendicular to the buccal alveolar bone surface. 


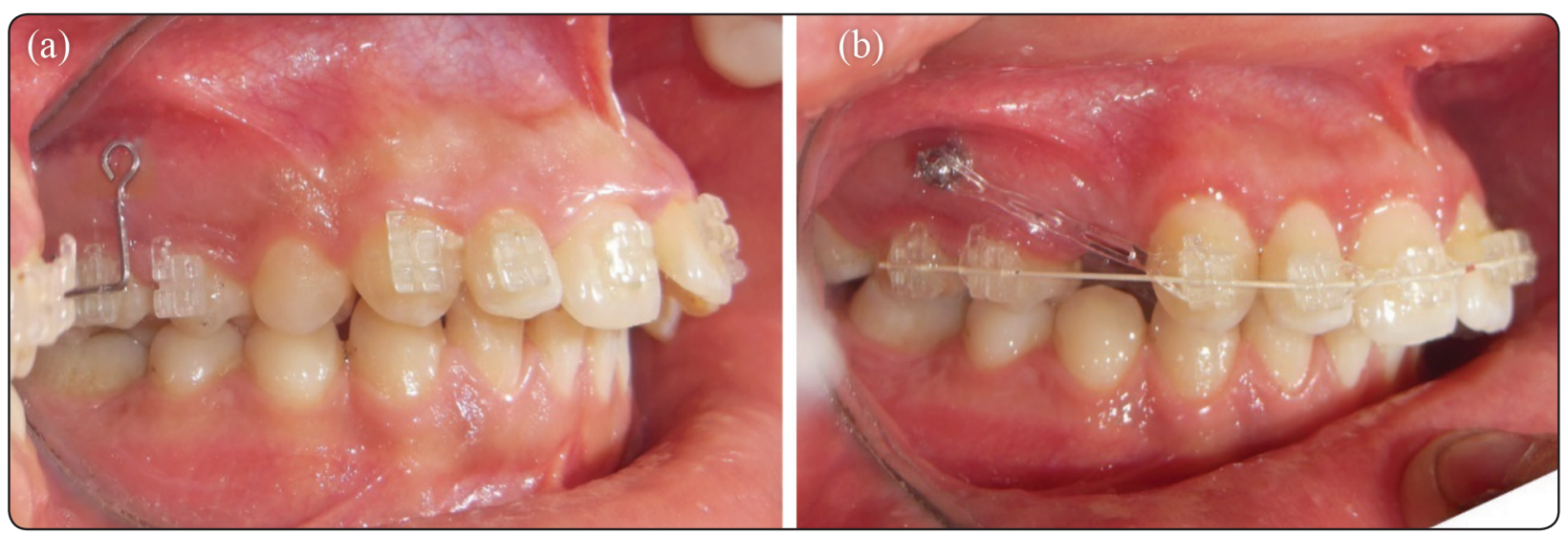

Fig. (1) Right side view showing (a) Before MSI insertion (L Shaped MSI insertion guide), (b) After insertion of MSI.

Canine retraction was commenced immediately after MSIs installation by sliding along 0.018"teflon-coated round St. St. arch wires. ${ }^{13}$ Canine retraction was started simultaneously in both sides by extending elastomeric chain (clear, short) between the head of the MSIs and the maxillary canine hooks.

Activation was done every three weeks (the elastic chain replaced by a new one) to have standardized force all over the experimental period. The initial force should be in the range of 200-250 gm to obtain the standardized canine retraction force (approximately $150 \mathrm{gm}$ ) after the first day sharp decay of force. ${ }^{14}$

All MSIs were removed either after four months of the experimental period and/or complete retraction of one of the canines into the extraction spaceby the application of counterclockwise torque load with the screwdriver supplied from the manufacturer. So, all MSI in the study had the same experimental period for standardization. ${ }^{13,15}$ After removal of MSIs, the orthodontic treatment was continued according to the proposed line of treatment for each patient.

\section{Clinical evaluation of the orthodontic MSIs:}

The orthodontic MSIs were clinically examined and photographed at every scheduled visit. The following signs and symptoms were examined and recorded: mobility, peri-implant inflammation, soft tissue impingement, inflammation in cheek opposite to MSI, movement of the MSI, pain, discomfort, and fracture of MSI.

Mobility was checked by using two rigid instrument grips. It was assessed on a two grade scale in which the score (zero) denotes no mobility, score (1) for slight mobility $(<1 \mathrm{~mm})$ and score (2) for excessive mobility $(>1 \mathrm{~mm})$. The mini-screw was considered successful if it proved stable throughout the treatment with scores ( 0 or 1$).{ }^{15}$

Evaluating the health of attached gingiva around MSI head was based upon the gingival color, and bleeding tendency. ${ }^{15}$

\section{Evaluation of oral hygiene condition:}

The simplified oral hygiene index (by Greene and Vermillion, 1964) was evaluated and scored for each patient before MSIs insertion, one week, one month, three months and four months after MSIs insertion as excellent (0), good (0.1-1.2), fair (1.3-3.0), or poor oral hygiene (3.1-6.0). ${ }^{16}$

\section{Oral mucosa sampling and assessment of DNA fragmentation by Comet assay:12,17,18}

1. It was collected immediately before MSIs insertion and (one week, one month, three months 
and four months) after MSIs insertion to identify DNA fragmentation of the investing tissue cells as a marker of cell health.

2. To remove exfoliated dead cells; the mucosal surfaces were gently scrubbed with cotton roll, and then the mouth was rinsed by normal saline for about 1 minute.

3. The mucosa samples were taken from different sites in the oral cavity, including areas; in direct contact to MSIs in the maxillary buccal gingiva, and in the cheek opposing the implant site. Oral mucosa samples were also collected from distant area in the mandibular buccal gingiva between first molar and second premolar, and in the cheek opposing same area in mandible for evaluating possible cytotoxic range of MSIs.

4. Asterile soft tapered nylon cytobrush (Cytobrush Plus, Medscand Medical, Germany) was used for cell collection by rolling the cytobrush on the mucosal surfaces. The cytobrush was inserted into a sterile, glass rubber seal-top test tube containing $1 \mathrm{ml}$ phosphate buffered saline solution (PBS) ( $\mathrm{pH} 7.4)$.

5. The glass tube containing the cytobrush cell collector was placed on the vortex vibrator for 30 seconds to extract the collected cells, and then the cytobrush was removed.

6. The collected mucosal cells were centrifuged for 1 minute at $1000 \mathrm{rpm}$, supernatant were discarded, and $5 \mathrm{ml}$ of PBS (pH 7.4) was added to the precipitated cells to form cell suspension.

7. Two $\mu \mathrm{g} / \mathrm{ml}$ of fluorescent ethidium bromide solution (working solution) were added to cell suspension and left for one hour. (Comet assay analysis)
8. The comet assay microscopically detects DNA damage at the level of a single cell with the aid of florescent DNA binding dye (Ethidium bromide). The dye measure nucleic DNA fragmentation through binding to the doublestranded nucleic acids as an intercalating dye, so testing the DNA super coils for the possibility of breaks by causing negative DNA super coiling upon its addition, the loops expanded out from the nucleoid core would form a comet.

9. Centrifugation at $2000 \mathrm{rpm}$ for 2 minutes was done, supernatant was discarded, deposits triple washed, and then added to microscopic slides with plastic covers.

10. The prepared slides were scanned by fluorescent microscope (magnification $=400 x$ ) using a 490$\mathrm{nm}$ excitation filter and a 530-nm barrier filter.

11. Microscopic photographic images (figure 2) were captured, optimized, and saved using a Spot real time (RT) camera running MetaVue software under a Nikon Eclipse E400 light microscope. At least three images of each sample were captured using a 400x magnification.

12. The percentage of oral mucosal cells with variable severity of fragmented DNA was assessed by observing the nucleus fluorescent activity. Increased mucosal cell DNA fragmentation was expressed by decreased nucleus fluorescent intensity.

13. At least calculation of one hundred cells were visually scored and given a percentage $\%$ score with the aid of image processing software (Image J- National Institute of Health NIH- USA) for measuring florescent stain density and for counting to evaluate DNA fragmentation score. 


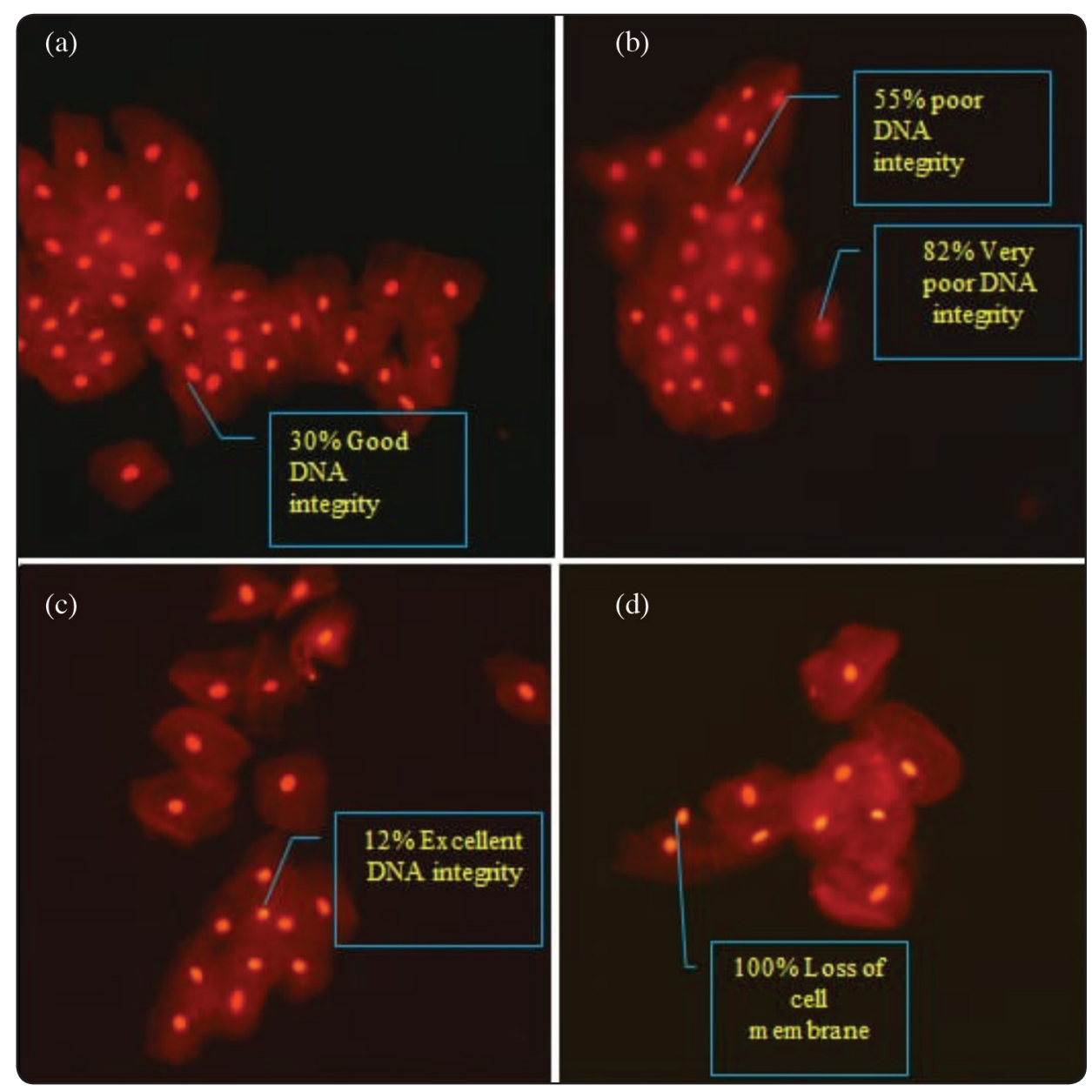

Fig. (2) Fluorescence photomicrographs (400x) showing individual oral mucosal cells with different DNA fragmentation score for measuring cellular DNA integrity (a) cell with good DNA fragmentation score, (b) cells with poor and very DNA fragmentation score, (c) excellent DNA fragmentation score, (a) loss of cell membrane (very poor DNA fragmentation score).

\section{DNA fragmentation index (DFI): ${ }^{19}$}

$$
\begin{aligned}
& <15 \% \text { DFI. } \\
& >15 \%<25 \% \text { DFI. } \\
& >25 \%<50 \% \text { DFI. } \\
& >50 \% \text { DFI. }
\end{aligned}
$$

Excellent DNA integrity

Good DNA integrity

Poor DNA integrity

Very poor DNA integrity
$>85 \%$ cell health.

$<85 \%>75 \%$ cell health

$<75 \%>50 \%$ cell health

$<50 \%$ cell health

\section{Statistical Analysis:}

The collected data was tabulated and statistically analyzed using SPSS 18 (SPSS Inc. (2009), IBM Corporation, Chicago, USA). The data was analyzed using ANOVA test followed by Tukey's post hoc test when ANOVA revealed a significant difference $(p \leq 0.05)$.

\section{RESULTS}

Orthodontic mini-screw implants were evaluated at different time intervals for any possible abnormal reactions. The table (1) revealed slight mobility (less than $1 \mathrm{~mm}$ ) after 3 months of clinical use (10\% of the sample). The mobility of MSIs was increased 
in the fourth month (more than $1 \mathrm{~mm}$ ) that led to failure of MSIs after four months of clinical use. The table also showed inflammation in the cheek opposite to $50 \%$ of the mini-screw implants after one week of insertion (Fig. 3). The cheek inflammation decreased to be only in $10 \%$ of the MSIs when evaluated after one month of insertion and $0 \%$ after the third month of insertion. Discomfort was experienced by $60 \%$ of patients in the first week after MSI insertion that disappeared thereafter.

TABLE (1) Frequency of abnormal reaction related to the orthodontic mini-screw implants (percentage \%).

\begin{tabular}{|c|c|c|c|c|}
\hline $\begin{array}{c}\text { (n= 30) } \\
\text { Peri-implant } \\
\text { inflammation } \\
\text { (\%) }\end{array}$ & $10 \%$ & $20 \%$ & $10 \%$ & $10 \%$ \\
\hline $\begin{array}{c}\text { Bleeding at } \\
\text { MSIs site (\%) }\end{array}$ & $0 \%$ & $0 \%$ & $0 \%$ & $0 \%$ \\
\hline $\begin{array}{c}\text { Score 1mobility } \\
\text { of MSIs (less } \\
\text { than 1mm) (\%) }\end{array}$ & $0 \%$ & $0 \%$ & $10 \%$ & $0 \%$ \\
\hline $\begin{array}{c}\text { Score 2 mobility } \\
\text { of MSIs (more } \\
\text { than 1mm) (\%) }\end{array}$ & $0 \%$ & $0 \%$ & $0 \%$ & $10 \%$ \\
\hline $\begin{array}{c}\text { Inflammation } \\
\text { in the cheek } \\
\text { opposite to } \\
\text { MSIs (\%) }\end{array}$ & $50 \%$ & $10 \%$ & $0 \%$ & $0 \%$ \\
\hline $\begin{array}{c}\text { Pain and/or } \\
\text { discomfort (\%) }\end{array}$ & $60 \%$ & $0 \%$ & $0 \%$ & $0 \%$ \\
\hline $\begin{array}{c}\text { Fracture of } \\
\text { MSIs (\%) }\end{array}$ & $0 \%$ & $0 \%$ & $0 \%$ & $0 \%$ \\
\hline
\end{tabular}

$n=$ number of mini-screw implants.

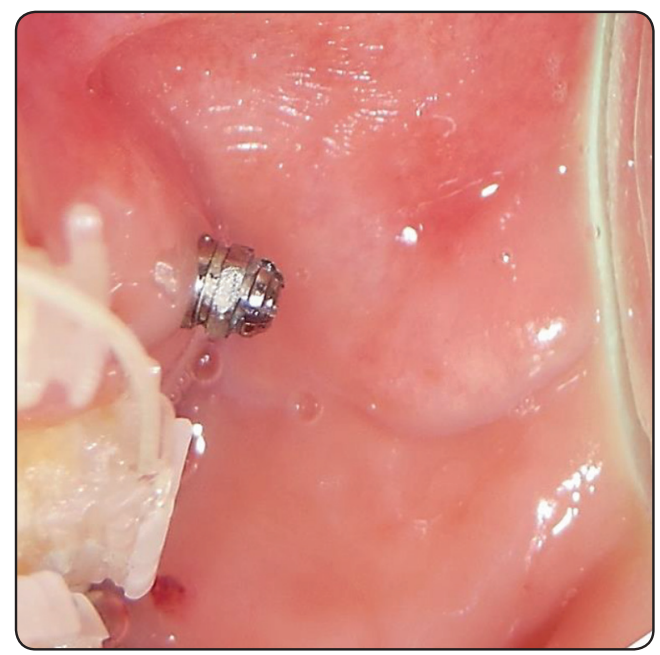

Fig. (3) Inflammation opposite to MSI in Left cheek

Oral hygiene index score gradually increased at one week, one month, 3 months and four months after MSIs insertion (table 2). ANOVA test revealed that the difference in Oral hygiene index score was statistically significant $(\mathrm{p}=0.05)$.

TABLE (2) ANOVA test that followed by Tukey's post hoc test for oral hygiene index score in different observation times.

\begin{tabular}{|c|c|c|c|c|c|c|c|}
\hline$(n=15)$ & Mean & SD & $\mathbf{S E}$ & Min & $\operatorname{Max}$ & $\mathbf{F}$ & P-value \\
\hline $\begin{array}{l}\text { Before } \\
\text { insertion }\end{array}$ & $0.83^{\mathrm{b}}$ & 0.25 & 0.08 & 0.50 & 1.16 & \multirow{5}{*}{5.33} & \multirow{5}{*}{$0.005^{*}$} \\
\hline One week & $1.13^{\mathrm{a}, \mathrm{b}}$ & 0.20 & 0.06 & 0.83 & 1.33 & & \\
\hline One month & $1.33^{\mathrm{a}}$ & 0.43 & 0.16 & 0.50 & 1.83 & & \\
\hline $\begin{array}{l}\text { Three } \\
\text { months }\end{array}$ & $1.46^{\mathrm{a}}$ & 0.43 & 0.15 & 1.00 & 2.33 & & \\
\hline $\begin{array}{l}\text { Four } \\
\text { months }\end{array}$ & $1.50^{\mathrm{a}}$ & 0.48 & 0.17 & 0.66 & 2.16 & & \\
\hline
\end{tabular}

Significance level $p \leq 0.05 . \quad *=$ significant .

$n=$ number of patients. $\quad S D=$ Standard deviation.

St.E. $=$ Standard error. $\quad$ Min.$=$ Minimum value.

Max. $=$ Maximum value .

Tukey's post hoc test: means sharing the same superscript letter were not significantly different. 
ANOVA test revealed that the difference in cytotoxicity of cells (Comet assay) (table 3 ) taken by swabs from around MSIs and from cheek opposite to MSIs (\%) was statistically insignificant ( $\mathrm{p}=0.52$, 0.76 respectively).
ANOVA test revealed that the difference in cytotoxicity of cells (Comet assay) (table 4) taken by swabs from mandibular buccal gingiva between first molar and second premolar (\%) and cheek opposite to mandibular buccal gingiva (\%) was statistically insignificant ( $\mathrm{p}=0.99,0.15$ respectively).

TABLE (3) Cytotoxicity of cells taken by swabs from around MSI in maxilla (\%) and cheek opposite to MSIs (\%) in different observation times (ANOVA test).

\begin{tabular}{|c|c|c|c|c|c|c|}
\hline \multirow[b]{2}{*}{$(\mathbf{n}=30)$} & \multicolumn{3}{|c|}{ Around mini-screw implants (\%) } & \multicolumn{3}{|c|}{ Cheek opposite mini-screw implants $(\%)$} \\
\hline & Mean $(\%)$ & SD & P-value & Mean $(\%)$ & SD & P-value \\
\hline Before insertion & 19.41 & 2.43 & \multirow{5}{*}{$0.52^{\mathrm{ns}}$} & 17.58 & 0.97 & \multirow{5}{*}{$0.76^{\mathrm{ns}}$} \\
\hline One week & 17.71 & 5.04 & & 17.79 & 4.07 & \\
\hline One month & 20.69 & 2.49 & & 18.15 & 4.84 & \\
\hline Three months & 19.62 & 3.63 & & 18.65 & 2.62 & \\
\hline Four months & 19.12 & 4.37 & & 19.39 & 2.89 & \\
\hline
\end{tabular}

$S D=$ Standard deviation.

Significance level $p \leq 0.05$.

TABLE (4) Cytotoxicity of cells taken by swabs from mandibular buccal gingiva between first molar and second premolar (\%) and cheek opposite to mandibular buccal gingiva (\%) in different observation times (ANOVA test).

\begin{tabular}{|c|c|c|c|c|c|c|}
\hline \multirow[b]{2}{*}{$(n=30)$} & \multicolumn{3}{|c|}{$\begin{array}{l}\text { Mandibular buccal gingiva between first molar } \\
\text { and second premolar }(\%)\end{array}$} & \multicolumn{3}{|c|}{$\begin{array}{l}\text { Cheek opposite the mandibular buccal gingiva } \\
\text { between first molar and second premolar (\%) }\end{array}$} \\
\hline & Mean (\%) & SD & P-value & Mean (\%) & SD & P-value \\
\hline Before insertion & 18.18 & 3.41 & \multirow{5}{*}{$0.99^{\mathrm{ns}}$} & 17.76 & 2.89 & \multirow{5}{*}{$0.15^{\mathrm{ns}}$} \\
\hline One week & 18.76 & 2.94 & & 16.01 & 3.64 & \\
\hline One month & 18.40 & 2.33 & & 16.08 & 4.43 & \\
\hline Three months & 18.70 & 5.05 & & 19.52 & 3.49 & \\
\hline Four months & 18.20 & 5.58 & & 18.14 & 2.96 & \\
\hline
\end{tabular}

SD = Standard deviation

Significance level $p \leq 0.05$. 


\section{DISCUSSION}

The current study was conducted on fifteen female orthodontic patients in need for extraction of maxillary first premolars and retraction of the canines into the extraction spaces. Each patient received two orthodontic MSIs serving as an anchorage which was a documented and preferred procedure in orthodontic anchorage. ${ }^{1,5,20}$

All recruited patients in the current study were female patients in order to avoid the effect of sexual dimorphism on any possible toxic effects of MSIs and to standardize as possible the study condition. In general it has been documented that sex was a factor considerably linked with the level of DNA damage and that this damage was higher in women. ${ }^{12,21}$

The oral hygiene was evaluated in different time intervals to study whether there was a correlation between the oral hygiene condition and the cytotoxicity \& failure rate of orthodontic MSIs. Despite the effort in improving patients' compliance to oral hygiene instructions during treatment, the accumulation of plaque and calculus increased. Such increase could be attributed to the difficulty in removing food debris from all around bonded multi-bracket system. The increase in dental plaque and calculus accumulation could have various drawbacks as the increased acidity of saliva, abnormal inflammatory response, and /or biocorrosion and failure of MSIs. ${ }^{5-7}$

These results were in agreement with previous studies that reported significantly increased accumulation of dental plaque, increased incidence of white spot lesion and caries occurrence during the first six months of fixed orthodontic appliance insertion. $^{26,27}$

The Comet assay was a widely used biomonitoring tool for DNA damage and the buccal cell model constitutes an attractive and potentially useful tool for investigating in vivo effects on DNA damage of dietary agents, lifestyle choices, chemical agents and xenobiotics in general. One of the main advantages of the Comet assay has been reported as it requested far lesser number of subjects and much fewer time than conventional epidemiology assays..$^{22,23}$

Material biocompatibility tested by in vitro methods was lacking the simulation of the oral cavity with its multifactorial environment. Furthermore, current in vivo clinical prospective study was aimed at representing the real condition of the oral cavity by sampling buccal cells, which were directly exposed to the orthodontic MSI. ${ }^{18,24}$

Besides, there were different reasons that support the use of buccal cell type, among others: it was the least invasive method available for measuring DNA damage, and these cells could represent a preferred target site for early genotoxic events induced by carcinogenic agents. ${ }^{18}$ In this regard, orthodontic appliances have been shown to induce genotoxicity in oral mucosa although the number of in vivo human studies on this topic still scarce.

But as far as we know, this was the first study that directed to evaluate clinically the possible influence of only Ti alloy MSIs in the genotoxic response of oral mucosa cells. This process was insured by using nonmetallic ceramic multi-bracket system in all teeth together with Teflon coated archwire which was changed every 3 weeks to avoid metal exposure occurred after coating failure of the archwire. So, the orthodontic MSI was the only metallic component present in the oral cavity that could release titanium, aluminum and vanadium ions with its supposed cytotoxic effects.

Buccal mucosa cells were collected at different time intervals (before insertion of MSI, 1week, 1 month, 3 months, and 4 months after MSIs insertion). It was reported that DNA damage could be observed in mucosa cells after 3 months of orthodontic treatment and not after 6 months of treatment, this might imply recovery from the initial DNA damage and tolerance to genotoxic agents. ${ }^{25}$

Our results was in agreement with most in vitro and in vivo study results. ${ }^{1,5,6,8,9,11}$ The result of the present study was coincident with the conclusion of similar clinical study since their results did not entail any additional increase in DNA damage. ${ }^{12}$ 


\section{CONCLUSION}

1. From biological point of view, the Ti alloy orthodontic mini-screw implants (MSIs) were biocompatible and demonstrated no cytotoxic effect on oral mucosa cells as evident by the absence of DNA fragmentation during the use of MSIs.

2. Despite the reduction in oral hygiene conditions, it didn't encourage any cytotoxic effects of MSIs.

\section{REFERENCES}

1. Ricardo CB, Roberta TB. In vitro study of human osteoblast proliferation and morphology on orthodontic miniimplants. Angle Orthod. 2015; 85: 920 - 6.

2. Sana S, Manjunath G. Mini- Implant Materials: An Overview. J Dent Med Sci. 2013; 7 (2): 15- 20.

3. Morais LS, Serra GG, Palermo EFA, Andrade LR, Muller CA, Meyers MA, et al. Systemic levels of metallic ions released from orthodontic mini-implants. Am J Orthod Dentofacial Orthop. 2009; 135: 522 - 9.

4. Sana S, Kumar A, Vaz AC. Comparison of elemental composition and morphological characteristics of orthodontic titanium mini-implants. J Orthod Res. 2016; 4 (1):18- 23.

5. Galeotti A, Uomo A, Spagnuolo G, Paduano S, Cimino R, Valletta $\mathrm{R}$, et al. Effect of $\mathrm{pH}$ on in vitro biocompatibility of orthodontic miniscrew implants. Prog Orthod. 2013; $14: 1-7$.

6. KosayadilokaK, Tangjit N, Luppanapornlarp S, Santiwong P. Metal Ion Release and Cytotoxicity of Titanium Orthodontic Miniscrews. Key Engineering Materials. 2017; 730: 141- 7 .

7. Blaya MG, Blaya CS, Mello P, Flores EMM, Hirakata LM. Titanium alloy miniscrews for orthodontic anchorage: an in vivo study of metal ion release. Rev OdontoCienc. 2011; 26(3):209-14.

8. Pithon MM, Santos RL, Martins FO, Medeiros PJ, Romanos MTV. Citotoxicity of orthodontic mini-implants. Rev Clin Pesq Odontol. 2010; 6(2):141- 6.

9. Malkoc S, Ozturk F, Corekci B, Bozkurt BS, Hakki SS. Real-time cell analysis of the cytotoxicity of orthodontic mini-implants on human gingival fibroblasts and mouse osteoblasts. Am J Orthod Dentofacial Orthop. 2012; 141: 419 - 26.
10. Mikulewicz M, Chojnacka K. Release of metal ions from orthodontic appliances by in vitro studies: a systematic literature review. Biol Trace Elem Res. 2011; 139:241 - 56.

11. Patwari M. Cytotoxicity of orthodontic temporary anchorage devices in vitro. Proquest Dissertations and Thesis. 2013; 197: 1- 60 .

12. Martín-Cameán A, Puerto M, Jos Á, Azqueta A, IglesiasLinares A, Solano E, et al. Preliminary study of genotoxicity evaluation of orthodontic miniscrews on mucosa oral cells by the alkaline comet assay. Toxicol Mech Methods. 2015; 25(6):487-93.

13. Jasoria G, Shamim W, Rathore S, Kalra A, Manchanda M, Jaggi N. Miniscrew Implants as Temporary Anchorage Devices in Orthodontics: A Comprehensive Review. J Contemp Dent Pract 2013; 14(5):993-9.

14. Ravi K, Balasubramaniam M R, George M, Duraisamy S. Comparison of canine retraction using slide friction less ligature modules with conventional modules- an in vivo study. Journal of Dental Science 2010; 1(2):150-5.

15. Justens E, De Bruyn H. Clinical Outcome of Mini-Screws Used as Orthodontic Anchorage. Clin Implant Dent Relat Res. 2008; 10: 174- 80.

16. Greene JC, Vermillion JR . The simplified oral hygiene index. J Am Dent Assoc. 1964; 68:1:7-13.

17. Kader HM, Aref MI, Hussein FA. Coating failure of commercial orthodontic magnets and DNA fragmentation of oral mucosa cells. Aust Orthod J. 2008; 24: 32 - 40.

18. Westphalen GH, Menezes LM, Prá D, Garcia GG, Schmitt VM, Henriques JAP, et al. In vivo determination of genotoxicity induced by metals from orthodontic appliances using micronucleus and comet assays. Genetics and Molecular Research. 2008; 7 (4): 1259-66.

19. Gonzalez-Acevedo A, Garcia-Sales JA, Gosalvez J, Fernández JL, Dávila- Rodríguez MI, Cerda-Flores RM, et al. Evaluation of environmental genotoxicity by comet assay in Columba Livia. Toxicol Mech Methods. 2016; 26 (1): 61- 6 .

20. Zhang L, Zhao Z, Li Y, Wu J, Zheng L, Tang T. Osseointegration of orthodontic micro-screws after immediate and early loading. Angle Orthod. 2010; 80:354 - 60.

21. Slyskova J, Lorenzo Y, Karlsen AS, Carlsen MH, Novosadová V, Blomhoff R, et al. Both genetic and dietary factors underlie individual differences in DNA damage levels and DNA repair capacity. DNA repair 2014; 16: 66-73.

22. Pereira da Silva VH, Gomes de Moura CF, Spadari-Bratfisch RC, Ribeiro DA. Cytogenetic biomonitoring of peripheral blood and oral mucosa cells from car painters. Toxicol Mechan Meth 2012; 22: 497-501. 
23. Dusinska M, Collins AR. The comet assay in human biomonitoring: gene-environment interactions. Mutagenesis. 2008; 23: 191-205.

24. Knutson KJ, Berzins DW. Corrosion of orthodontic temporary anchorage devices. Eur J Orthod. 2013; 35; 500- 6.

25. Hafez HS, Selim EMN, Eid FHK, Tawfik WA, Al-Ashkar EA, Mostafa YA. Cytotoxicity, genotoxicity, and metal release in patients with fixed orthodontic appliances: a lon- gitudinal in-vivo study. Am J Orthod Dentofacial Orthop 2011; 140:298-308.

26. Tufekci E, Dixon JS, Gunsolley JC, Lindauer SJ. Prevalence of white spot lesions during orthodontic treatment with fixed appliances. Angle Orthod. 2011; 81 (2): 206- 10.

27. Zotti F, Dalessandri D, Salgarello S, Piancino M, Bonetti $\mathrm{S}$, Visconti L, et al. Usefulness of an app in improving oral hygiene compliance in adolescent orthodontic patients. Angle Orthod. 2016; 86 (1): 101- 7. 